\title{
Effectiveness of Mandatory Labor Report in Company of Network for Provision of Company Data
}

\author{
Jamaludin Al Ashari ${ }^{*}$ and Arpangi ${ }^{* *}$ )
}

*) Student of Master of Law, Faculty of Law, Universitas Islam Sultan Agung Semarang, E-mail : jamalsala3@gmail.com

**) Lecturer of Master of Law, Faculty of Law, Universitas Islam Sultan Agung Semarang.

\begin{abstract}
.
This study aims to determine and analyze the effectiveness of the application of compulsory employment reports in networks (online) in supporting the provision of company data in districts/cities, especially in Salatiga. The research method used in this writing is sociological juridical. Based on the research, it is concluded that the enforcement of mandatory employment reports in companies in the network (online), in terms of reporting speed, helps the government and entrepreneurs or company administrators to carry out their reporting obligations, but in terms of quantity and quality of reporting, it is considered ineffective in supporting the provision of company data in the City of Salatiga.
\end{abstract}

Keywords: Mandatory Labor Reports; Authority; Labor Inspectors.

\section{Introduction}

One of the data needed in development is labor data, and one of the objects of employment data is company data. In the nomenclature in the government, to find out company data, the search is to the agency that deals with manpower, at the central level it is the Ministry of Manpower, while at the regional level it is the agency that deals with manpower. In the regions, apart from the office that deals with manpower, data can also be found on the agency that deals with licensing, the office that deals with industry and trade. There are also vertical agencies that intersect with labor, for example the Social Security Administration (BPJS), both BPJS Ketenagakerjaan and BPJS Kesehatan as well as the Central Statistics Agency (BPS) in each district/city, which have separate data.

To collect company data, the Ministry of Manpower uses the instrument of Act No. 7 of 1981 concerning Obligatory Report on Employment in Companies. This law becomes the basis for the Ministry of Manpower and regional manpower offices to collect company data. This law was born to replace Act No. 23 of 1953 concerning the Obligation to Report Companies. ${ }^{1}$ To implement Act No. 7 of 1981, the Ministry of Manpower made implementing regulations in the form of ministerial regulations. Now, what applies is the Minister of Manpower Regulation Number 18 of 2017 as amended by the Minister of Manpower Regulation Number 4 of 2019 concerning Mandatory Procedures for Reporting Employment in Online

\footnotetext{
${ }^{1}$ General Elucidation of Act No. 7 of 1981 concerning Obligation to Report Manpower in Companies, Supplement to the State Gazette of the Republic of Indonesia of 1981 Number 3201.
} 
Companies. $^{2}$ Prior to the enactment of the Minister of Manpower Regulation Number 18 of 2017, there were several ministerial regulations governing it. The Minister of Manpower Regulation Number 18 of 2017 puts forward reporting by companies in the network or online at the address, https://wajiblapor.kemnaker.go.id.

Based on Article 4 of Act No. 7 of 1981 concerning Obligatory Report on Employment in Companies, it requires every entrepreneur or manager to report in writing every time he establishes, stops, re-runs, transfers or dissolves a company to the minister or authorized official. ${ }^{3}$ In addition, entrepreneurs or managers are required to report annually in writing regarding manpower to the minister or appointed official. ${ }^{4}$ The report must contain information, including but not limited to company identity, labor relations, protection of workers work, and job opportunities and others. ${ }^{5}$

Regarding the data reported online, go directly to the data base of the Ministry of Manpower. This is different from the previous ministerial regulation which regulates the reporting model manually through the local manpower office (district/city), then in stages it is reported to the manpower agency above.

Where does the company report it? Referring to Article 4 Paragraph 1 of Act No. 7 of 1981, reporting is addressed to the Minister or appointed official. The Minister in this case is the Minister of Manpower. The appointed official, citing the Elucidation of Article 4 Paragraph 1, is an official entrusted with the task of monitoring in the area of manpower in the regions. ${ }^{6}$

In practice, there are problems regarding officials in the regions entrusted with the task of monitoring in the manpower sector, especially after the tasks or matters of supervision in the manpower sector have been transferred to the provincial government from regencies/cities, as mandated by Act No. 23 of 2014 concerning Regional Government.

It is important to know, since the Old Order and the New Order, the matter of labor inspection is the authority of the ministry in charge of manpower (central). Continuing in the era of regional autonomy until 2014, the affairs of labor inspection were divided into central affairs (the ministry that deals with manpower), provincial government affairs (the agency that deals with manpower in the province), and the district/city government (the agency that deals with manpower in districts/cities). This is confirmed in Article 178 Paragraph 1 of Act No. 13 Year 2003 concerning Manpower, which stipulates that pThe labor inspection is carried out by a separate work unit within the agency that has the scope duties and responsibilities in the field of manpower in the central government, government province, and district/city government. ${ }^{7}$ Thus, in the era of regional autonomy, according to the Elucidation of Article 4 Paragraph 1 of Act

\footnotetext{
2 Jdih.kemnaker.go.id accessed on October 2, 2020.

3 Act No. 7 of 1981 concerning Obligation to Report Manpower in Companies (State Gazette of the Republic of Indonesia of 1981 Number 39).

4 Ibid, Article 7.

5 Ibid, Article 6.

${ }^{6}$ Additional Elucidation to the State Gazette Number 3201 (Article by Article). Op.cit.

${ }^{7}$ Act No. 13 of 2003 concerning Manpower (State Gazette of the Republic of Indonesia of 2003 Number 39).
} 
No. 7 of 1981, the reporting of manpower data is addressed to the manpower office in the district/city, because at that time it was still in charge of labor inspection.

Since 2014, according to Act No. 23 of 2014 concerning Regional Government, the authority for labor inspection at the district/city level has been removed. Now the lowest labor inspection authority lies with the provincial government. As a consequence, reporting in the case of mandatory labor reporting also changes to the province which has the authority or affairs of labor inspection. In accordance with Act No. 23 of 2014 concerning Regional Government, Roman Annex I Letter $G$, the division of governmental affairs in the field of labor, for the sub-sector of labor inspection, is a concurrent affair between the central government and the provincial government. ${ }^{8}$ This is an elaboration of the text of Article 9 of Act No. 23 of 2014. For the division, the central government is in charge of establishing a system of labor inspection and management of labor inspectors, while the provincial government is in charge of the implementation of labor inspection. ${ }^{9}$

The transfer of labor inspection affairs, including personnel and infrastructure to this province, has an impact on the office in charge of manpower in the district/city. The impact, among others, is that a number of manpower offices in districts/cities cannot update company data, due to "loss" of company data source instruments, after they no longer have the authority to receive company data reports based on Act No. 7 of 1981.

With the background of these problems, this research will examine how the effectiveness of the enforcement of mandatory employment reports in networked (online) companies in supporting the provision of company data, especially in the City of Salatiga.

According to Hans Kelsen, legal effectiveness is legal norms in society that must be implemented and implemented based on applicable regulations. This means that legal norms serve as guidelines for society to act according to orders. There are two important aspects in law, including the static aspects (nomostatics) of actions which are governed by law, and the dynamic (nomodinamic) aspects of the laws that govern certain actions. ${ }^{10}$

Regarding authority, according to HD Stoud, as quoted by Ridwan HB, is the overall rules relating to the acquisition and use of governmental authority by public legal subjects in public legal relations. ${ }^{11}$ In relation to the implementation of Act No. 7 of 1981, according to Act No. 23 of 2014 which obtains and uses authority is the Ministry of Manpower and the provincial offices in charge of labor inspection. This authority is in the form of receiving, managing labor data reporting in accordance with Act No. 7 of 1981 and implementing law enforcement for violations of this law and its implementing regulations.

\footnotetext{
${ }^{8}$ Briefing Paper of the Minister of Manpower in the 2015 National Labor Inspection Coordination Meeting.

${ }^{9}$ Roman Appendix I Letter G Act No. 23 of 2014 concerning Regional Government.

10 Peter Mahmud Marzuki. (2008). Pengantar Ilmu Hukum. Jakarta : Kencana. p.158.

11 Dahwadin, and Hasanudin. (2020). Peradilan Agama di Indonesia. Wonosobo: CV. Mangku Bumi Media. p. 11.
} 
Based on the description of the background above, this study aims to determine and analyze the effectiveness of the application of compulsory employment reports in networked (online) companies in supporting the provision of company data in districts/cities, especially in Salatiga.

\section{Research methods}

The research method used in this writing is sociological juridical. This research is based on normative legal science (laws and regulations). This research examines the norm system in statutory regulations and observes how the reactions and interactions that occur when the norm system works in society. This research is also often referred to as law in action research. Sutandyo said that sociological juridical research falls into the category of doctrinal legal research on in-concreto law. ${ }^{12}$

\section{Results and Discussion}

The effectiveness of the mandatory employment report in companies online or online for the provision of company data in districts/cities, one of which is in the City of Salatiga, is influenced by two factors, namely the factor of management authority to report employment in companies, and the factor of law enforcement against violations of Act No. 7 of 1981 concerning Obligations to Report Manpower in Companies in conjunction with the Minister of Manpower Regulation Number 18 of 2017.

Act No. 7 of 1981 concerning Obligatory Reporting of Employment in Companies and its implementing regulations are part of the legal system applicable in Indonesia. In order to make it effective, according to Paul and Dias' view, as quoted by Esmi Warassih, there are 5 (five) conditions that must be met, namely: ${ }^{13}$

- It is easy or not the meaning of the legal rules to be grasped and understood;

- The extent to which there are circles in society who know the contents of the legal rules concerned;

- Efficient and effective mobilization of legal rules;

- There is a dispute resolution mechanism that is not only easily accessible and accessible to every member of the community, but also has to be quite effective in resolving disputes, and;

- There is a common perception and acknowledgment among the community that these legal rules and institutions are indeed capable of being effective.

First, regarding whether the meaning of these legal rules is easy to grasp and understand, as a legal regulation, Act No. 7 of 1981 concerning Obligations to Report Manpower in Companies, is actually a rule whose meaning is easily captured and understood by the public, in this case the business community. or the management of the company and the government, especially the ministry/service

\footnotetext{
12 Djulaeka, Devi Rahayu. (2019). Buku Ajar Metode Penelitian Hukum. Surabaya: Scopindo Media Pustaka. p.76.

13 Esmi Warassih. (2016). Pranata Hukum: Sebuah Telaah Sosiologis. Semarang : Pustaka Magister. p.74.
} 
that deals with manpower. However, when it has entered the technical realm in the workforce reporting system in the company as outlined in the Minister of Manpower Regulation Number 18 of 2017 concerning Mandatory Procedures for Reporting Employment in Networked Companies, the community, in this case the employer or company management, does not all understand or understand the provisions. the.

This condition causes the mandatory reporting of employment in companies in the network to not run optimally. In Salatiga, for example, it is evident from 376 companies that have been registered manually, when they were transferred online, only 362 companies had registered. ${ }^{14}$ This number does not include companies that have not fulfilled their reporting obligations at all.

The 362 companies, only 159 companies filled in completely on the mandatory online reporting form so that they could find out the complete company data. The rest, namely 202 registered companies, only registered for an account. ${ }^{15}$ As a result, company data, such as the number of male and female workers, wages, social security membership, and protection of occupational safety and health, cannot be recorded or reported.

Second, whether there are circles in society who know the contents of the legal rules concerned. The targets or objects of Act No. 7 of 1981 and its implementing regulations are among entrepreneurs or managers of companies and social enterprises that employ workers. Companies that are regulated by this law are not limited in certain limitations. All types of companies, regardless of their workforce, whoever owns them, are legal entities or not, even social enterprises that employ people, are included in the circles regulated by this law.

The reality on the ground, those who are familiar with Act No. 7 of 1981 concerning Obligatory Reporting of Employment in Companies and the contents of these laws are mostly from medium and large scale companies. Micro and small scale companies, individual companies and social enterprises employing people such as foundations, are rarely aware of the law. Whereas what is regulated in Act No. 7 of 1981 includes them.

Third, whether or not it is efficient and effective to mobilize legal rules.In the system of forming laws and regulations in Indonesia, the theory of legal fiction still applies, where everyone is considered to know the law if it has been promulgated in an official document. A person's ignorance of the applicable laws or regulations does not exempt that person from legal prosecution (igronantia iuris neminem excusat).

Act No. 7 of 1981 is actually not new because it was enacted 40 years ago. With this legal fiction theory, of course, it is assumed that entrepreneurs or company managers understand these regulations. The massive mobilization of the Law on Mandatory Labor Reporting in Companies and its effective implementing regulations will be able to provide understanding to employers/their management regarding their obligation to report employment.

Output from the law is the presence of manpower data from companies, but the fact is that not a few employers or managers are ignorant of the presence of

14 End of 2020 Report, Semarang Region Labor Inspection Unit.

15 Ibid 
this law. Why do so many entrepreneurs refuse to report? Because the majority of businessmen think it is useless to report. They feel that they have no interest or benefit/benefit for the company when they have to report because in this position the government has an interest in, namely the need for data. ${ }^{16}$

Fourth, the existence of effective dispute resolution in statutory regulations. In the case of the enactment of Act No. 7 of 1981, it can be said that the articles do not invite and contain content that can be disputed. Even if there are disputes, the tendency is in State Administration disputes between entrepreneurs/company managers and State Administrative Officials, namely Labor Inspectors and heads of agencies in charge of manpower. This dispute may originate from the issuance of an Audit Note given by the Labor Inspector to entrepreneurs deemed to have violated Act No. 7 of 1981. On the other hand, the employer/management may not accept the audit note because he feels that he has not violated the law. the law. Indeed, so far, there has been no dispute regarding this matter.

Fifth, a The equal opinion and acknowledgment of society among the citizens of Act No. 7 of 1981 and its implementing regulations that this regulation has the capacity to be effective can be seen from two sides of the community/society. First, from the government, in this case the parties in the ministry/agency in charge of manpower. Second, among entrepreneurs/company management.

The opinion of the agencies in charge of manpower, the enactment of Act No. 7 of 1981 concerning Obligatory Employment Reporting in Companies, realizes that it is still not effective. Especially now with the enforcement of mandatory employment reports in companies in the network. This is evident in the number of companies that report, up to the third year of the implementation of the mandatory online manpower report, it is still small when compared to when reporting manually. Also, after reporting online, the employment data entry is still empty.

The advantage of being online is that the speed of labor data recapitulation is quickly presented at the same time, whereas in manual reporting, the recapitulation of labor data recorded through the mandatory labor reporting instrument is very slow.

Second, the opinion of employers/company management regarding the Law on Obligatory Labor Reporting in Companies and its implementing regulations, is now even more effective. Entrepreneurs/company managers who are accustomed to carrying out reporting obligations have a positive response and consider that the mandatory report on employment in the network is very effective for the company. This is evident, from 29 respondents in the study, who gave answers when asked about the effectiveness of the mandatory online employment report, 27 respondents (93.1\%) claimed to be effective, while 2 respondents (6.9\%) stated that they were ineffective. However, what about the businessmen/company management who don't know about the regulations at all? They certainly don't implement the regulation.

\section{Institutionalization and Internalization Process}

16 Interview with Marwoto, SH. Industrial Relations Mediator of the Salatiga Manpower Office. 
Strengthening the application of compulsory labor reports in companies online or online as a new order or regulation in the employment reporting system requires institutionalization and internalization in the framework of establishing legal awareness among entrepreneurs/company administrators. According to Soerjono Soekanto, as quoted by Esmi Warassih ${ }^{17}$ In order to instill new values so that they can be institutionalized as new patterns of behavior in society, it is necessary to have a process of institutionalization and internalization in the framework of forming public legal awareness. Likewise, with the enforcement of the mandatory online reports of manpower regulations, institutionalization and internalization processes are required in order to build awareness among entrepreneurs/company administrators.

Quoting Soetandyo Wignyosoebroto, as quoted by Esmi Warassih ${ }^{18}$ The effectiveness of instilling these new values is a positive result of the use of human labor, tools, organizations and methods to instill new institutions in society. The use of human labor here is how the bureaucracy works. This process requires a sincere commitment and high ability from the officers in implementing the policies contained in the law.

Likewise, in instilling new values in the application of mandatory online labor reports in companies, bureaucracy is needed starting from the ministry of manpower to the manpower office that has a sincere commitment and high ability to implement these new policies/regulations.

Adequate facilities and a tidy organization also support efforts to introduce new policies, including new rights for the people who are the target of the regulation. Likewise, the facilities in the online mandatory reporting of employment services need to be improved so that they are able to provide excellent service to entrepreneurs/company administrators, such as the smoothness of the internet network and the ease of use of information technologybased services. Also, organizations/institutions that are in charge of the management of manpower reports need clarity of authority.

A serious effort needs to be made because it must be realized that every attempt to plant something new will inevitably meet with resistance from parties who feel aggrieved. If this form of resistance is not properly managed by the executive officer, it will have a negative effect on the success of the institutionalization process.

Therefore, quoting Soerjono Soekanto ${ }^{19}$, a neat monitoring system must also be developed, and efforts to make them aware of these new elements continue to be instilled and emphasized. The length or shortness of the time required for the cultivation of new elements also determines its success. The hurriedly the people try to plant and the sooner they expect the results, the less positive the effect that arises from the institutionalization process. Likewise, on the contrary, the effectiveness of the speed of these planting efforts cannot actually be seen independently, but must be related to the factor of effectiveness in implanting new

\footnotetext{
${ }^{17}$ Esmi Warassih. Op.cit.

18 Ibid.

19 Ibid.
} 
elements. Increasing planting speed coupled with efforts to increase effectiveness will not reduce the results of the institutionalization process.

Therefore, to borrow Soerjono Soekanto's term, namely that a neat inspection system must be developed, the labor inspection for the application of Act No. 7 of 1981 in a neat manner by labor inspectors also deserves to be developed.

\section{Closing}

Enforcement of mandatory employment reports in companies in the network (online), in terms of reporting speed, helps the government and entrepreneurs or company managers to carry out their reporting obligations, but in terms of quantity and quality of reporting, it is deemed ineffective in supporting the provision of company data in Salatiga City. Ineffectiveness because the authority of district/city offices including the Salatiga Industry and Manpower Office is limited by law so that the office cannot carry out management, guidance, socialization, supervision and legal action. on the application of Act No. 7 of 1981 concerning Mandatory Manpower Reporting in conjunction with Regulation of the Minister of Manpower Number 18 of 2017 as amended by Regulation of the Minister of Manpower Number 4 of 2019 concerning Mandatory Procedures for Online Reporting of Manpower. In addition, there are long distances both geographically and in administrative areas made by law, so that parties who are given the authority to carry out management, guidance, socialization of supervision and legal action related to the application of Act No. 7 of 1981 concerning Mandatory Manpower Reporting and its implementing regulations, namely the Ministry of Manpower and the Provincial Office of Manpower and Transmigration (Semarang Regional Labor Inspection Unit), are unable to carry out their functions effectively and optimally.

With such a reality, it is necessary to expand the authority in order to streamline the application of mandatory labor reports in companies. The legal source of authority in the management of compulsory labor reports in companies is Act No. 7 of 1981 Article 4 Paragraph (1) and its Elucidation. Article in Act No. 7 of 1981 is counterproductive to Act No. 23 of 2014 concerning Regional Government, especially the Annex which regulates labor inspection authority.

The relationship between these two laws and regulations is that the management and inspection of labor reports is carried out by the sector in charge of labor inspection, which is the authority of the central and provincial governments. On the other hand, the object of Act No. 7 of 1981 concerning the compulsory employment report in companies and their supervision is companies located in districts/cities.

\section{References}

\section{Books:}

[1] Dahwadin, and Hasanudin. (2020). Peradilan Agama di Indonesia. Wonosobo : CV. Mangku Bumi Media. 
[2] Djulaeka, Devi Rahayu. (2019). Buku Ajar Metode Penelitian Hukum. Surabaya : Scopindo Media Pustaka.

[3] Esmi Warassih. (2016). Pranata Hukum: Sebuah Telaah Sosiologis. Semarang: Pustaka Magister.

[4] Peter Mahmud Marzuki. (2008). Pengantar Ilmu Hukum. Jakarta: Kencana.

[5] Satwasker Wilayah Semarang, Laporan Akhir Tahun 2020 Data Wajib Lapor Ketenagakerjaan di Perusahaan, Satuan Pengawasan Ketenagakerjaan Wilayah Semarang

\section{Paper:}

[1] Briefing Paper of the Minister of Manpower in the 2015 National Labor Inspection Coordination Meeting

\section{Regulations:}

[1] Act No. 7 of 1981 concerning Obligations to Report Manpower in Companies.

[2] Act No. 13 of 2003 concerning Manpower.

[3] Act No. 23 of 2014 concerning Regional Government.

[4] Regulation of the Minister of Manpower Number 18 of 2017 concerning Procedures for Obligatory Networking of Manpower Reporting. 